\title{
Carpeaux: mediador entre a literatura das "duas Espanhas" e o Brasil
}

VALERIA DE MARCO

$\mathrm{N}$ O CAMPO dos estudos literários, Otto Maria Carpeaux tem amplo reconhecimento tanto por sua grandiosa História da literatura ocidental como por seus escritos para jornais e revistas. Entre as várias motivações desse reconhecimento, talvez algumas sejam especialmente relevantes nesta época de culto à especialização: o fato de Carpeaux entender que a reflexão sobre a literatura possibilita compreender seu próprio tempo; ter ele o processo de comparação entre obras e autores como força propulsora de seu pensamento e, talvez como decorrente de ambas, o gesto de desafiar a prática institucionalizada da historiografia literária, fundada, desde a era romântica, na associação entre língua, pátria e tradição literária nacional, prática que já desde o início no século XX não acomodava muitos escritores importantes que, de modo forçado ou voluntário, abandonaram a língua materna para expressarem-se. Certamente, esses traços, além de outros, devem-se à sua formação humanista e à sua própria história de vida.

Filho de pai judeu e mãe católica, nasceu Otto Karpfen em 9 de março de 1900 em Viena. Frequentou diferentes universidades: na sua cidade estudou matemática, física e química; em Paris, sociologia; e, em Nápoles, literatura comparada. Sempre retornando a seu país, em 1925, ali se doutorou em Filosofia e Letras. Essa formação e os ares de um centro cultural tão vivo como a Viena das primeiras décadas do século XX deram a ele o perfil pleno de um grande humanista. Obteve um cargo no governo local e, até a anexação da Áustria à Alemanha, em 1938, escreveu muito, publicando vários livros, entre os quais talvez o mais relevante seja $A$ missão europeia da Áustria, de 1935, e empenhando-se em contribuir para o jornalismo político na defesa da independência de seu país ante o avanço do projeto nazista de construção da "Grande Alemanha”. Em 1938, com a polícia política no calcanhar, saiu de Viena para a Antuérpia. No ano seguinte, decidiu abandonar o continente europeu tomado pela convulsão dos dois meses que antecederam o início da Segunda Guerra Mundial e veio para o Brasil. Depois de instalar-se precariamente no Paraná, viajou a São Paulo e entrou em contato com Álvaro Lins que lhe abriu as portas dos círculos literários do Rio de Janeiro. Em 1941, afrancesou seu nome e iniciou sua longa carreira de colaborador do Correio da Manhã, publicando artigos dedicados a temas literários. 
Naturalizou-se em 1942, ano em que começou a dirigir a biblioteca da Faculdade Nacional de Filosofia e publicou A cinza do purgatório, o primeiro de uma série de livros nos quais reuniria seus escritos que haviam circulado em jornais e revistas. A partir de 1964, usou como e quando pôde seu espaço na imprensa para lutar contra o golpe militar e a ditadura, calando-se só ante a imposição da censura. Morreu em 1978, sem poder acompanhar o fim do estado de exceção.

Muitos são os depoimentos da rápida integração desse intelectual austríaco nos ambientes literários da capital do Brasil e da alta qualidade de seu trabalho. Vale a pena destacar um deles, menos conhecido entre nós, o do sociólogo e escritor Francisco Ayala, uma vez que seu testemunho indica vínculos de Carpeaux com outros espaços da América Latina. Ayala era uma figura relevante do grande contingente de pensadores e artistas espanhóis que se exilaram ao final da Guerra Civil Espanhola e a consequente ditadura do general Franco. Instalara-se na Argentina. Sobrevivia dando aulas em diferentes universidades e colaborando com editoras, como Losada ou Sudamericana. Passou todo o ano de 1945 no Rio de Janeiro, lecionando sociologia na universidade e no Itamaraty. Quando chegou à cidade, Gabriela Mistral, então cônsul do Chile, recomendou-lhe que entrasse em contato com Carpeaux. Ayala não o fez imediatamente, mas manteve-se atento, como recordou muitos anos depois: "Pronto empecé a ver la firma de Carpeaux al pie de articulos muy densos y ricos en los periódicos de Rio" (Ayala, 2006, p.312-13). Logo passou a conviver com Carpeaux e em seu livro de memórias, escrito em Madri, depois da morte de Franco, registrou os traços mais significativos de seu exercício crítico: "Entre mis libros tengo una Historia da literatura ocidental en cuatro voluminosos tomos, publicada por él en 1962, en alguna de cuyas páginas creo escuchar como un eco de las conversaciones nuestras. Es la obra de un humanista lleno de sabiduría y dotado de una visión amplia y profunda" (ibidem, p.313).

A lembrança parece fundar-se nos fatos. Durante sua estada no Rio de Janeiro, Ayala frequentou a casa de Carpeaux e ficou muito impressionado pela atividade daquele exilado, sobrevivente como ele das catástrofes do século XX, cujo espírito não se abateu, como atestavam sua presença constante na imprensa e seu intenso trabalho de composição dessa história monumental que começa com a literatura grega e chega aos primeiros anos da década de 1940. De fato, de 1942 a 1945, Carpeaux escreveu a Historia da literatura ocidental e entregou o manuscrito de quase cinco mil páginas datilografadas ao editor. Por problemas econômicos da editora, a obra foi publicada somente em 1959, já com uma atualização do texto original.

Como observa Ayala, amplitude e profundidade são as marcas permanentes dos escritos de Carpeaux, duas características que bastante raramente se combinam na atividade historiográfica, tão presa a uma visão panorâmica, a um discurso pautado pela sucessão cronológica de épocas, autores e obras de uma determinada tradição nacional e que costuma dedicar alguma densidade a 
escritores canonizados em séculos passados. Ciente disso, Carpeaux (2011, p.4) dialoga com essa prática no prefácio à primeira edição de sua história:

[...] as literaturas européias (e as americanas) não foram estudadas separadamente, assim como não se fez separação alguma entre a poesia e a prosa e os chamados gêneros literários. Cada um dos capítulos refere-se a todas as manifestações de determinado estilo em todas aquelas literaturas. Em vez de uma coleção de histórias da literatura, pretendeu-se esboçar a história dos estilos literários, como expressões de fatores sociais modificáveis, e das qualidades humanas permanentes. Os critérios da exposição historiográfica são, portanto, estilísticos e sociológicos.

Tanto nessa obra como em seus textos para jornais ou revistas, Carpeaux sempre procurou desvendar as complexas relações entre a(s) forma(s) artística(s) e o espírito da época (Zeitgeist). A tal perspectiva crítica deve-se acrescentar uma dimensão ética de sua escritura: seu compromisso com a liberdade de pensamento, expresso no profundo respeito ao seu leitor, à sua formação e ao ambiente cultural em que ele vive. Ele tinha consciência de que o dever do crítico é contribuir para a ampliação do horizonte de reflexão do leitor e de que o contato entre ambos exigia um discurso que proporcionasse um lugar de encontro de sensibilidades, impressões, valores e saberes, um lugar a partir do qual se analisa o passado para compreender o presente. Essa dimensão da atividade de Car-peaux também ficou gravada na memória de Francisco Ayala (2006, p.314-5):

Cuando [..] regresé a Buenos Aires y empecé a editar la revista Realidad, le pedi su colaboración a mi amigo Carpeaux, y tuve el placer de publicar en uno de los primeros números un espléndido ensayo de su pluma sobre La torre, de Hugo von Hofmannsthal, un drama donde el poeta simbolista austriaco reelabora, con vistas a los problemas de su tiempo, La vida es sueño, de Calderón.

O ensaio a que se refere Ayala, publicado no segundo número de Realidad, correspondente aos meses de março e abril de 1947, é em um rigoroso estudo de literatura comparada. Consiste em distinguir como os diferentes desfechos da ação dramática de ambos os textos, construída em torno ao personagem do príncipe prisioneiro que é educado no ambiente de tensão entre sonho e realidade e libertado pelos súditos, interpretam a significação política do regime monárquico: na obra de Calderón de la Barca supera-se a rebelião palaciana e a monarquia é revitalizada; no início do século XX, com a morte do príncipe Segismundo, o simbolista austríaco encena a dissolução do mesmo regime.

Comparar as diferentes elaborações do núcleo desse ensaio feitas por Carpeaux permite observar seu respeito ao leitor. Seu miolo é pouco mais que um parágrafo em "Hofmannsthal e o seu Gran Teatro del Mundo", texto que integrou $A$ cinza do purgatório, seu primeiro livro publicado no Brasil e no qual o autor reuniu artigos que circularam em 1941 e 1942 no jornal Correio da Manhã e na Revista do Brasil. Para apresentar a trajetória do desconhecido escritor alemão e dar destaque à peça que aparece no título do texto, dirige-se ao leitor brasileiro mencionando a colaboração de Hofmannsthal como libretista de ópe- 
ra de Strauss, compositor que um amplo público podia identificar. Já o ensaio publicado em Realidad, revista destinada a um público mais restrito, mais culto e familiarizado com a literatura espanhola, Carpeaux começa o texto considerando que essa tradição literária forjou três "mitos": o Quixote, símbolo do homem-poeta; Don Juan, o do homem-sexo, e Segismundo, o do homem-político. Estabelecendo assim o diálogo com o leitor, o ensaio retoma a comparação esboçada anteriormente na versão brasileira e desenvolve uma minuciosa análise das duas obras dramáticas. Em 1953, esse mesmo longo estudo comparativo foi publicado no Brasil, sob o título "A torre", tendo sido recolhido em seu livro Respostas e perguntas, mas apresenta uma nova forma de exposição. Para criar um canal de diálogo com o leitor, Carpeaux suprime as referências aos símbolos da literatura espanhola, comenta um tema do debate político da conjuntura brasileira e ressalta a dimensão política das duas peças teatrais e de seu próprio interesse como crítico:

Embora o presente ensaio tratasse de um assunto de literatura comparada, é preciso confessar desde já sua origem em estudos de ciência política. Fala-se muito, hoje, em "problema de liberdade", quer dizer, na antinomia entre Liberdade e Autoridade, ou então entre liberdade social e liberdade intelectual. (Carpeaux, 1999, p.520)

Se, por um lado, essas reelaborações da leitura contrastiva de Calderón de la Barca e de Hofmannsthal mostram a dimensão ética da escritura de Carpeaux, expondo seus valores e o lócus de sua enunciação, por outro, indicam uma necessidade de desenvolver o tema para propor não apenas uma visão do passado, mas também uma interpretação desse tempo presente no qual compartilha inquietudes com seu leitor:

A estranha coincidência das expressões (refere-se a variações de "todos sueñan lo que son" / "la vida es sueño" y "cenizas") lembram as origens espanholas da civilização vienense, ligada à península ibérica pela dinastia, pela fé católica, pelo estilo da arquitetura e da vida. Se existe possibilidade de interpretar aquele "mito" espanhol-barroco de uma maneira pela qual o elemento permanente humano do assunto (a vida como sonho) revivifique a doutrina política (presa na "torre encantada" do enredo) - então só pode ser, tomando-se como ponto de partida aquele resto (ruína misteriosa) do mundo espanhol que ainda subsiste: a Áustria. O último poeta dessa antiga Áustria foi Hofmannsthal, que chegou realmente a escrever nova versão de Vida es sueño: Der Turm (A torre). [...] as visões diferentes do mesmo assunto interpretam-se mutuamente. (ibidem, p.523)

A análise da significação de imagens e conceitos que estruturam as duas obras - vida, sonho, torre, educação e sabedoria - dá a Carpeaux a possibilidade de formular uma hipótese de interpretação das relações culturais e políticas dos contextos tão diferentes em que foram produzidas. Postula que "O Estado espanhol e a ideia do império universal encontram-se na pessoa de Carlos V" (ibidem, p.528). Depois de reconstruir o entorno erasmista desse monarca, afirma: "Do erasmismo, quer dizer, do humanismo cristão, pretendeu o imperador 
fazer o fundamento espiritual da Monarquia europeia" (ibidem, p.528) e que o projeto fracassou porque a Igreja deixou de apoiar o rei; “o papa Paulo III venceu o universalismo europeu" (ibidem, p.528). Por isso, Carpeaux entende que a contrarreforma abriu caminho para o pensamento nacionalista e para a derrota dos ideais universalistas.
A Espanha dos Felipes ficou "torre coronada" mas já de "muros desmorona- dos”, ruína magnífica, reino do sonho. Em 1898, o sonho acabou. Mas na Áus- tria dos Habsburgos ainda sobreviveu o último resto do império de Carlos V, também já desmoronado, mantendo-se apesar dos esforços dos incompetentes que a governaram. (ibidem, p.528-9)

Para o crítico, os poetas do barroco espanhol, bem como os do século XX que os leram conscientes do abismo existente entre a maioria da sociedade e o Estado coercitivo, captam esse processo histórico representando-o reiteradamente na imagem da torre:

$\mathrm{O}$ símbolo Torre pertence à linguagem política da poesia espanhola. De excelso muro, oh torres coronadas, fala Góngora. Mas em Quevedo a torre já ameaça ruína: seus muros desmoronados de la patria mía antecipam as decrépitas ciudades que povoam a Castela de Antonio Machado. O cântico da decadência castelhana de Unamuno, refere-se ironicamente a Madrigal de las altas torres. (ibidem, p.527)

Importante é destacar que a relação entre o barroco espanhol e o século XX não é linear nem contínua; ela consistiria em uma linha de força para interpretar reciprocamente as duas épocas, pois, exatamente porque a arte barroca capta a desagregação de um modelo humanista e europeísta, ela é a expressão melancólica do isolamento do artista perante o mundo que se desmorona ao redor de si.

O homem barroco encontrou a segurança na torre inviolável de sua alma; pagou, por isso, o preço de desvalorização do mundo exterior, desmascarado como sendo sonho e "vanitatum vanitas" [...] o individuo, excluído dos postos de mando nas altas torres do estado, retirou-se para a torre de sua alma: prisão, é certo, mas que permitiu observar com serenidade o desmoronamento dos "excelsos muros" da outra torre. (ibidem, p.528)

As três versões da comparação entre as peças de Calderón e de Hofmannsthal, por construírem uma rede de relações entre a literatura da Espanha do século XVII e a vitalidade cultural do império austro-húngaro, sugerem uma dimensão mais profunda do interesse de Carpeaux pelo barroco espanhol: uma perspectiva para compreender sua época, o desastre da desaparição de seu país, a catástrofe da Segunda Guerra Mundial, as ameaças à liberdade no debate de ideias no cenário na guerra fria, a desvalorização da voz do intelectual na esfera política, ou seja, um modo de compreender-se a si mesmo. Talvez se possa verificar a pertinência dessa hipótese observando o campo literário e político em que se situa a maioria de seus escritos sobre a literatura espanhola. Essa produção concentra-se nos autores do século XX que viveram os projetos internacionalistas da II República Espanhola (1931-1936), os embates e combates da Guerra Civil e suas consequências. 
O ensaio "Gongora e o neogongorismo" pode exemplificar como o trabalho crítico de Carpeaux sobre a literatura espanhola era impulsionado pelo movimento de interpretar reciprocamente o barroco e o desmoronamento das utopias humanistas do século XX. Escrito no mesmo período de seu primeiro texto sobre Hofmannsthal e o barroco espanhol, foi incorporado no livro Origens e fins, publicado, como $A$ cinza do purgatório, também em 1942, e que também reunia os artigos escritos entre 1941 e 1942 para jornais e revistas. No ensaio, depois de informar o leitor sobre o empenho de críticos e escritores como Alfonso Reyes, José María de Cossío, Miguel Artigas, Dámaso Alonso e Gerado Diego para resgatar Gongora, depois de traçar uma analogia entre essa trajetória de leitura do poeta espanhol, decisiva para sua integração ao cânon literário, e a de Donne, Carpeaux desenvolve a hipótese de que, em ambos os casos, o sentido da revitalização de suas obras vincula-se ao espírito da época dos artistas modernos, a um novo confronto com uma profunda crise social. Conclui Carpeaux:

Deste modo, a poesia barroca e a poesia moderna esclarecem-se mutuamente. Gongora reaparece no popularismo do Romancero gitano e no hermetismo da "Oda al Santísimo Sacramento del altar", de García Lorca, na angiologia e nos gritos revolucionários de Rafael Alberti. [...] A poesia moderna não pode deixar de ser assim, numa "noche negra" de "reveses, catástrofes, descalabros y fracasos". Como Gongora, estamos exilados em "soledades". Mas a própria "noche negra" da "infame turba de noturnas aves" anuncia, com a força própria da dialética histórica, "la estación florida", a aurora futura. (ibidem, p.312)

A adesão de Carpeaux aos poetas espanhóis que cultivaram o neogongorismo é bastante mais intensa no ensaio "García Lorca", também incorporado ao livro Origens e fins. Nele, o crítico constrói uma visão ampla, integradora e ética da trajetória poética de Lorca. Começa o texto contextualizando sua leitura do poeta: confessa que demorou quinze anos para compreender o sentido de seus versos e expõe como e por que pôde fazê-lo durante os primeiros anos da Segunda Guerra Mundial.

O mundo, parecia-me, perdera o sentido. Hoje porém o próprio poeta morto respondeu pelos seus últimos poemas (se refere aos poemas de Poeta en Nueva York $^{1}$ ) aos meus escrúpulos. E já me sinto capaz de depor - depoimento de consciência moral - sobre a poesia e a morte de García Lorca. (ibidem, p.313)

O problema literário que Carpeaux não equacionara quinze anos antes consistia em avaliar em que medida o sucesso do livro Romancero gitano decorria da exaltação de seu autor à Espanha pitoresca e na dificuldade de compreender como uma poesia tão intensamente nacional alcançara rapidamente uma significação universal. O crítico encontrou uma resposta para essas perguntas nos últimos poemas de Lorca, uma vez que neles pulsava a mesma angústia antes captada pelo poeta na vida dos ciganos de sua Andaluzia. Mas a compreensão profunda dessa resposta só lhe fora possível nos primeiros anos da Segunda Guerra Mundial, pois só então se dera conta de que aquele sentido universal re- 
sultava da significação do assassinato do poeta. Reconhecendo que tal violência não era uma excepcionalidade, mas sim resultado de uma lógica determinada, retoma a história de Lorca, esse "filho predileto dos da geração de 98" (ibidem, p.319), esse “poeta da República Espanhola de 1931" (ibidem) e procura explicá-la. Depois de considerar que a geração de 98 "é herdeira legítima da liberdade intelectual dos humanistas do século XVI" (ibidem, p.318), porque "era bem espanhola e bem europeia, ao mesmo tempo", "uma geração de espíritos independentes" (ibidem), Carpeaux afirma:

Pela geração de 98 e pela República de 31, a Espanha se havia tornado, pela primeira vez desde séculos, o país exemplar da Europa: daí a significação universal de sua poesia popular, regionalista. Nessa república popular de intelectuais, o velho abismo entre a Inteligência e o Povo desaparecera: símbolo disso, a poesia, popular e moderníssima ao mesmo tempo, de García Lorca. (ibidem, p.319)

Seguindo o movimento de composição desse ensaio o leitor percebe que nele há mais que uma adesão do crítico ao sentimento do mundo que pulsa na poesia de Lorca: Carpeaux transforma o poeta em símbolo de uma geração de intelectuais e se identifica com ele tão intensamente que se apropria de seus versos para denunciar o caráter hipócrita do pacto de "Não Intervenção" das supostas democracias europeias na Guerra Civil Espanhola:

A morte de García Lorca, tragédia espanhola, tem significação europeia, universal, como a sua poesia. A morte de García Lorca não foi um fato absurdo; foi uma demonstração rigorosa do verdadeiro estado de coisas num mundo em que os capitalistas administram a Liberdade, em que os propagandistas administram a Verdade, em que os carrascos administram a Justiça, em que os capelães de cárcere administram a Caridade. "Todo se ha roto en el mundo." Mas - como costumavam dizer os estadistas da Não-Intervenção? - Recuso-me a acreditar... Não quiseram ver a "Sangre derramada"

No.

!Yo no quiero verla!

[...] à Não-Intervenção na Espanha seguiu-se a Não-Intervenção na Tchecoslováquia; ao fim da Espanha, o fim da Europa. "No quisieron verla". (ibidem, p.319-20)

Essa compreensão da vitalidade da arte espanhola durante a II República e da que se produziu no campo republicano durante a Guerra Civil - "A Espanha foi o primeiro país europeu em que a poesia readquirira uma significação pública” (ibidem, p.319) - não se constrói apenas com as operações habituais de uma elaboração crítica, mas também com a emotividade gerada por um sentimento de comunhão de valores. No sangue derramado na Espanha está também o sangue de Carpeaux, levando-o a evocar sempre a tragédia espanhola e o compromisso de reparação que ela exigia, como explicitou no ensaio "Angustia e esperança de Antonio Machado”, escrito depois do final da Segunda Guerra Mundial. Nesse texto, o crítico chama a atenção para a distância entre o poeta e as vanguardas; analisa sua singularidade em relação à geração de 98 , ao debate 
sobre a poesia pura, a Juan Ramón Jiménez e ao grupo de 1927. E conclui que a poesia de Antonio Machado revelou seu caráter universal com o passar do tempo, quando a lemos no contexto da catástrofe europeia:

A sua poesia tem significação universal: só parecia estreitamente espanhola enquanto a Espanha dos seus dias era o último canto esquecido da Europa. Essa Espanha não reconquistou e não reconquistará o perdido império colonial. Mas em outro sentido voltou a ser uma grande potência: uma potência moral. Pedra de toque da consciência do mundo. (ibidem, p.624-5)

A partir dessa perspectiva crítica forjada pelo compromisso de defesa da liberdade, Carpeaux empenhou-se em divulgar, na imprensa do Rio de Janeiro e de São Paulo, a literatura produzida nas duas Espanhas - a peninsular e a peregrina - nascidas da Guerra Civil e da longa ditadura franquista. Certamente seus contatos com os intelectuais que viviam na Argentina, no Chile e no México, com professores universitários que trabalhavam em instituições canadenses e norte-americanas e, especialmente, com o hispanista Gustav Siebenman, seu amigo suíço, possibilitavam-lhe acesso a informação e a livros que se editavam durante os anos em que viveu no Rio.

No caso, os contatos com intelectuais e escritores de outros países eram importantes, pois, à diferença de livros franceses, norte-americanos, ingleses e portugueses, nos centros culturais brasileiros a circulação da literatura espanhola limitava-se às obras dos clássicos dos séculos XVI e XVII. São conhecidas as razões históricas dessa limitação. A elite letrada brasileira reproduzia as relações de dependência típicas de país periférico: colônia portuguesa até princípios do século XIX, o Brasil gira em torno das metrópoles culturais da época contemporânea, ou seja, França, até o final da Segunda Guerra Mundial e, depois, Estados Unidos. Como também se sabe nunca houve, e ainda não há, uma relação orgânica, fluente e recíproca entre o Brasil e seus vizinhos da América do Sul. Considerando tal contexto, é notório o pioneirismo de Carpeaux, pois durante mais de trinta anos ofereceu ao público brasileiro não somente a possibilidade de ampliar o contato com diversas tradições literárias, convidando-o sempre a explorar relações entre elas, como também a de mantê-lo atualizado sobre o que se ia produzindo em vários países. E, como era consciente das barreiras linguísticas e do provincianismo dos centros brasileiros, sempre insistiu na necessidade do debate sobre políticas de tradução, pois, nesse campo, distinguia com lucidez a perversa conjunção da lógica do mercado editorial com as relações de favor que caracterizam a implantação e a modernização do capitalismo no Brasil. Mas, apesar de saber que pouco ou nada podia intervir nos planos das editoras, com a autoridade construída em seus artigos, recomendava obras que deveriam ser traduzidas para o português, considerando-as em razão de valores estéticos e da possibilidade que elas ofereciam de refletir sobre o mundo contemporâneo.

O elenco de autores e obras das "duas literaturas espanholas, a de dentro e a de fora" (ibidem, p.807) é bastante extenso: Francisco Ayala, Max Aub, Ra- 
món Sender, José Bergamín, Arturo Barea, Rafael Alberti, Jorge Guillén, Pedro Salinas, León Felipe, Juan Ramón Jiménez, Luis Cernuda, Ignacio Aldecoa, Jesús Fernández Santos, Dámaso Alonso, Camilo José Cela, José María Gironella, Dionísio Ridruejo, José María Pemán, Vicente Aleixandre, Gerardo Diego, Miguel Delibes, Juan Goytisolo, José Corrales Egea, Jesús López Pacheco y pensadores, como José Ortega y Gasset y María Zambrano.

Seria impossível resenhar aqui os comentários de Carpeaux sobre tantos autores. Mas tomemos dois textos para exemplificar como sua perspectiva é fiel ao respeito à liberdade de pensamento, como afinidades ou divergências ideológicas não interferem em sua avaliação estética das obras e como acompanhava o que se ia publicando. O primeiro, "Almas no purgatório", é um ensaio sobre La colmena de Camilo José Cela. O texto traz os dados básicos sobre a produção e a biografia do romancista, sublinhando inclusive sua filiação política ("Pertence à Falange" [Carpeaux, 1999, p.807]) e dá as informações sobre trajetória da obra: sua proibição na Espanha, a publicação em Buenos Aires, como ocorreu com muitos textos censurados pelo regime franquista, e seu sucesso de venda em Nova York. Considerando-a como a "mais notável” entre os romances escritos na Espanha depois da Guerra Civil, Carpeaux comenta-a articulando duas operações críticas: por um lado, analisa a singularidade de sua forma, cujo traço fundamental seria a sequência de cenas cotidianas aparentemente desconexas, em consonância perfeita com o estilo paratático, que resulta na construção de um caleidoscópio de imagens da sociedade; e, por outro, compara-a constantemente com outras obras, para ressaltar como La colmena difere do realismo do século XIX e dialoga com o neorrealismo de outros contextos literários de então:

[...] o neo-realismo ocidental de hoje, sejam seus representantes comunistas italianos ou falangistas espanhóis, é um recomeço, porque é o encontro com uma realidade inesperada e asperamente nova: a Itália depois do fascismo, a Espanha depois da guerra civil. São realidades recém-criadas. Não são realidades recém-descobertas como as que encontrou o romance neonaturalista de 1930 na América Latina, inclusive no Brasil. Vejo nessa diferença a atualidade especial de La colmena para os leitores brasileiros. O neo-realismo, a que não se prestou entre nós (fora do cinema) a devida atenção, será capaz de indicar-nos caminhos novos, depois do evidente esgotamento do assunto nordestino. (Carpeaux, 1999, p.808)

Cabe observar que na composição desse ensaio, além de escrever sobre o romance de Cela e avaliá-lo tão positivamente, Carpeaux também explicita que sua perspectiva crítica pauta-se pelo interesse na relação entre as duas Espanhas, quando interpreta o gesto de Barea:

quem escreveu o prefácio laudatório da edição americana foi Arturo Barea, autor da trilogia de romances La forja de un rebelde, um dos mais eminentes escritores antifranquistas exilados. La colmena é a primeira ponte sobre o abismo que separa as duas literaturas espanholas, a de dentro e a de fora. Já se vê que é um livro extraordinário. (ibidem, p.807) 
O segundo ensaio selecionado a título de exemplo é "A descoberta de Aub". ${ }^{2}$ Ele não só demonstra a atenção de Carpeaux à produção dos exilados espanhóis de 1939, como também atesta uma capacidade ímpar de manter-se informado sobre as obras que se iam publicando. O texto, com o propósito de resenhar Jusep Torres Campalans, ${ }^{3}$ romance de Max Aub, editado no México em 1958, apresenta a trajetória do escritor repassando muitas das obras escritas por ele no exílio: peças de teatro, livros de contos, os três - Campo cerrado, Campo de sangre, Campo abierto - dos seis romances que viriam a compor posteriormente El laberinto mágico, e, de modo mais surpreendente, Sala de Espera, uma revista fundada por Aub para publicar textos exclusivamente seus e que teve 30 números, editados no México entre 1948 e 1951. Depois de comentar a composição do romance, Carpeaux finaliza o texto compondo um perfil do escritor, no qual Aub se reconheceu, como consta na carta que lhe enviou do México, e sugerindo, uma vez mais, sua adesão aos valores desse homem que tanto escrevia sobre a catástrofe da Espanha e da Europa:

O romance de Aub é sátira sutil e cruel: contra o cabotinismo de tantos pintores modernos; contra a máquina de publicidade dos "marchands" parisienses; contra a credulidade dos críticos de arte que aceitam tudo, por medo de parecerem atrasados; contra o aviltamento da erudita história da arte [...] mas, principalmente, contra uma vanguarda que venceu comodamente no mundo burguês [...]. É sátira contra os que abandonaram os incômodos problemas morais, quando fica resolvido o problema de sua própria vida e carreira. Mas são esses problemas morais que Max Aub não abandonou. (Carpeaux, 1961, s. p.)

Até mesmo apenas a leitura dos trechos aqui citados dos artigos de Car-peaux permite observar que o aspecto mais original de seu papel de mediador entre a literatura espanhola do século XX e o leitor brasileiro consiste em que sua crítica se constrói a partir da perspectiva da prática comparatista e não do ângulo de visão do hispanista. Este tende a dirigir-se a um público mais restrito, àqueles que procuram alimentar um universo cultural pelo qual já têm um certo interesse ou que já lhes é familiar, enquanto a prática da comparação, por mobilizar referências de diversas tradições literárias, contribui para ampliar o público leitor e lhe oferece o acesso a um novo repertório literário.

E, para concluir, ressalte-se outro aspecto dessa intermediação pioneira entre a literatura das duas Espanhas do século XX e o Brasil: tem Carpeaux uma enunciação militante. Quer ele compartilhar com o leitor brasileiro as múltiplas maneiras de refletir sobre as utopias derrotadas na Espanha, sobre aquele momento especial da História do Ocidente em que, a seu juízo, haviam sido abolidas as fronteiras entre o povo e o intelectual e, sobretudo, entre línguas e países. E, nessa medida, sua obra ganha o estatuto de testemunho e de lugar de memória, como ele mesmo reconheceu:

Mesmo que a "questão espanhola" - questão política para todos os homens livres e questão moral para os intelectuais responsáveis - venha a desaparecer temporariamente da atualidade política, continuará o dever da consciência intelectual: lembrar sempre e sempre a Espanha. (Carpeaux, 1999, p.625) 


\section{A descoberta de Aub}

\section{Otto Maria Carpeaux}

Entre os numerosos escritores, nacionais e estrangeiros, que dedicaram romances e novelas à guerra civil espanhola - basta lembrar os nomes de Barea, Gironella, Hemingway, Dos Passos, Malraux -, ocupa Max Aub uma posição singular, já que não é possível chamá-lo de estrangeiro nem de nacional. Lutou ao lado dos republicanos. Vive no exílio mexicano. No entanto, a revista madrilena a "Insula", desafiando a censura, dedicou-lhe um artigo, intitulado "El español Max Aub". Realmente? E o nome alemão?

Max Aub é filho de alemão e de mãe francesa. Nasceu em Paris em 1903. Quando, em 1914, estourou a Primeira Guerra Mundial, seus pais tomaram atitude que chamaríamos hoje europeia: incapazes de decidir-se contra a França ou contra a Alemanha, igualmente queridas, emigraram para a Espanha. Max Aub cresceu em Valência. Ligou-se às vanguardas literárias e artísticas da Espanha de Unamuno, Ortega, Machado, Baroja, Ramón Gomez de la Serna, Picasso; e aos anarquistas. Lutou na guerra civil no campo republicano. Fugiu através dos Pireneus, experimentou a miséria dos campos de concentração na França; e da invasão alemã fugiu para o México, onde publica seus livros e onde editou uma revista com título dolorosamente característico para a existência de exilado: "Sala de espera".

México fica longe da Europa. Os livros mexicanos, proibidos na Espanha, não são lidos em Paris. Max Aub ainda espera para ser descoberto. Pouco se sabe da sua vida; o pouco que sei, devo-o ao escritor suíço Gustav Siebenmann, que há alguns anos se esforça para divulgar as obras de Aub nos países de língua alemã.

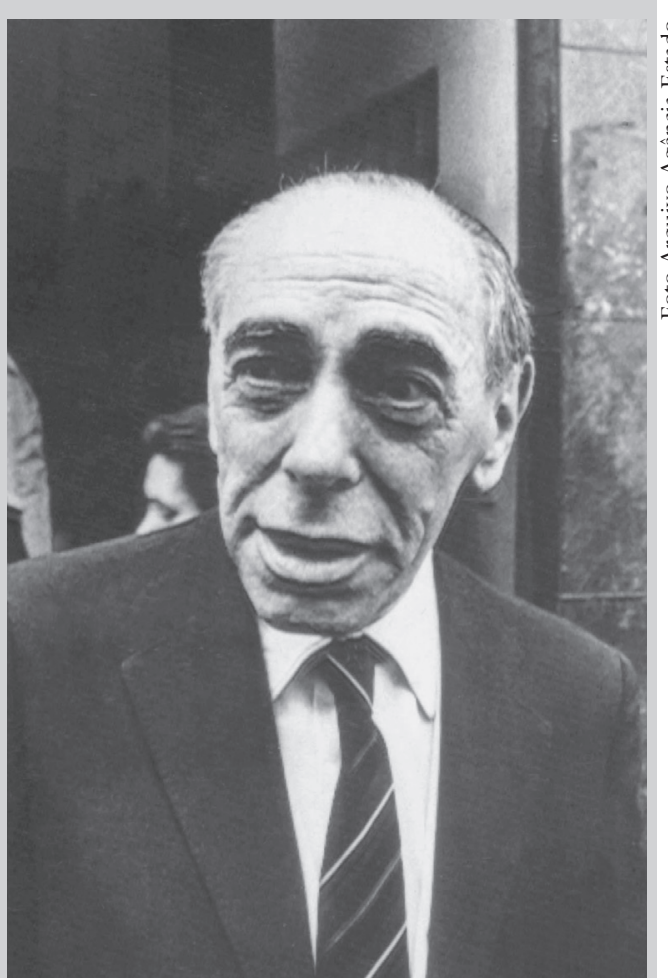

Otto Maria Carpeaux (1900-1978)

Aub é homem de muitas facetas e atividades. Em primeira linha, é romancista e novelista. Dedicou à Guerra Civil espanhola uma trilogia de impressionantes romances: "Campo cerrado", "Campo de sangre" e "Campo abierto"; e numerosos contos magistrais: "No son cuentos", "Ciertos cuentos", "Cuentos ciertos". Escreveu, mais, várias peças teatrais. Preocupa-se apaixonadamente com as artes plásticas; ele próprio é pintor sofrível. E essa ocupação com a arte levou-o à sua grande descoberta. Em 1955, viajando pelo Estado mexicano de Chiapas, encontrou um velho espanhol (ou antes, catalão) que vive ali entre os índios, esquecido e tendo esquecido seu passado parisiense de 1910, quando frequentava o "Lapin agile" e o Montmartre de Utrillo e foi amigo de Picasso, Nonell e Braque. Se ficasse ali, talvez fosse hoje um pintor de fama universal. Mas preferiu, como Gauguin, uma outra vida. Agora o mundo, instruído por Max Aub, terá de conhecer-lhe o nome: Jusep Torres Campalans.

A descoberta foi noticiada em Paris. Alguns velhos ainda se lembraram vagamente de Torres Campalans; menos Picasso, que, provavelmente por ciúmes artísticos, afirmou não saber nada desse seu patrício. Mas Jean Cassou, o maior conhecedor daquela época e 
diretor do Musée National d'Art Moderne, conseguiu reunir alguma documentação. Os "marchands" começaram a perguntar pelos quadros do catalão, garantindo bons preços. Aub resolveu escrever um livro, que saiu em 1959, no México. A tradução francesa, devida a Alice e Pierre Gascar, acaba de sair em Paris (Gallimard): é dedicada a André Malraux.

O livro começa com um vivo panorama da época: a França da Terceira República e a Inglaterra vitoriana, as lutas dos pintores impressionistas, os primeiros automóveis e os primeiros cinemas, o caso Dreyfus e a música de Debussy, a Exposição Internacional de Paris em 1900, a Belle Époque e o anarcossindicalismo de Sorel, a crise de Marrocos, a guerra nos Balcãs e a poesia de Apollinaire, a primeira revolução russa e os cubistas no Montmartre, e o tiro que em 1914 matou Jean Jaurès e foi o primeiro tiro da guerra mundial. Eis o "background" da vida de Jusep Torres Campalans.

Foi uma vida obscura. Ninguém se lembrava. Max Aub devia investigá-la como se fosse um romance policial; mais ou menos assim como Symonds reconstruiu a vida do bizarro Barão Corvo. Jusep Torres Campalans nasceu em 1886 em Mollerusa (Catalunha). Cresceu em Gerona. Foi para Barcelona, onde encontrou o jovem Picasso; existe uma fotografia amarelada, reproduzida no livro de Aub, que mostra os dois rapazes lado a lado. Campalans também começou a pintar. Também foi para Paris, onde ganhou a vida como estivador nas Halles, até conhecer a pintora alemã Annemarie Merkel, irmã no espírito de Marie Laurencin, que o sustentava. Foi recusado pelo Salon d'Automne de 1906. Frequentava círculos anarquistas. Foi amigo de Apollinaire, Max Jacob, Picasso. Encontrou Rilke e Mondrian. A questão só era: ter paciência, até chegar à glória. Mas a catástrofe de 1914 sacudiu ao jovem pintor cubista a consciência. Fugiu para o México onde Aub o encontrou, 40 anos depois: vivendo com um harém de índias, esquecido do mundo e tendo esquecido o mundo.

A última parte do livro: transcrição de cadernos do artista; catálogo das obras preservadas; reprodução de uns 50 quadros, acompanhados de abundantes notas eruditas que situam a arte de Campalans dentro da evolução da pintura moderna.

Os "marchands" parisienses não conseguiram nada. Todos aqueles 50 quadros, expostos no ano passado em México numa sensacional individual, já foram vendidos. A documentação escassa reunida por Jean Cassou chegou às mãos dele por intermediários a serviço do próprio Aub. A fotografia do jovem Campalans ao lado do jovem Picasso é uma fotomontagem. Malraux e o grande perito Cassou foram barbaramente iludidos. Jusep Torres Campalans é personagem inventado por Max Aub, que também pintou aqueles quadros. O livro é romance.

Quem não foi iludido é o velho Picasso. Afirma-se que ele se riu muito dos outros, embora não sem certa amargura. Pois ele também é dos atingidos pela sátira.

O romance de Aub é sátira sutil e cruel: contra o cabotinismo de tantos pintores modernos; contra a máquina de publicidade dos "marchands" parisienses; contra a credulidade dos críticos de arte que aceitam tudo, por medo de parecerem atrasados; contra o aviltamento da erudita história das artes, que trata qualquer troca-tintas contemporâneo como se fosse objeto de estudo como um Piero della Francesca ou Vermeer van Delft; mas, principalmente, contra uma vanguarda que venceu comodamente no mundo burguês.

É sátira à maneira espanhola: assim como no "Don Quijote", esconde-se atrás do riso o sentido moral de uma "novela ejemplar". É sátira contra os que abandonam os incômodos problemas morais, quando fica resolvido o problema de sua própria vida e carreira. Mas são esses problemas morais de nossa época que Max Aub não abandonou. São testemunhas disso seus livros sobre a Guerra Civil Espanhola e a epígrafe de um dos seus contos, encontrada em Pascal: "Si ce que je dis ne sert à vous éclaircir, il servira au peuple. Si ceux-lá se taisent, les pierres parleront".

Deseja-se que a "descoberta" de Max Aub sirva para o mundo descobrir o próprio Max Aub e se lembrar dos graves motivos que lhe inspiraram a obra. 
1 A referência de Carpeaux a este livro de García Lorca é mais um dado para atestar sua capacidade de manter-se informado. Como se sabe, essa obra não se perdeu porque José Bergamín, editor da prestigiosa revista Cruz y Raya, conseguiu recuperar o manuscrito antes de deixar Madri, durante a Guerra Civil, e publicou-o em 1940 na editora Seneca, fundada pelos exilados republicanos logo depois de chegarem à cidade do México.

2 Como este artigo de Carpeaux não está ainda disponível na edição recente de sua obra reunindo sua produção publicada apenas na imprensa, o leitor o encontrará transcrito neste artigo.

3 Para compreender a pertinência e a contundência do comentário de Carpeaux é preciso ter em conta alguns dados sobre a obra, além daqueles que estão no artigo. Trata-se de um romance em que Aub abusa da fraude como recurso de composição. Apresenta-se como biógrafo de Campalans, um pintor catalão que deixara o pincel e o continente europeu no início da Primeira Guerra Mundial e fora viver em Chiapas. O romance tem uma estrutura cubista, superpondo textos de natureza diversa, fotos de quadros e um catálogo de uma exposição da obra do pintor inviabilizada pelos bombardeios a Londres durante a Segunda Guerra Mundial. Contando com a cumplicidade de escritores mexicanos, como Fuentes e Paz, a de Picasso e a de Jean Cassou, a obra foi lançada com uma exposição dos quadros que apareciam reproduzidos no livro. O mercado de arte moveu-se à procura de outras obras de Campalans e o livro de Aub foi catalogado como um título de História da Arte.

\section{Referências}

AYALA, F. Recuerdos y olvidos. Madrid: Alianza, 2006.

CARPEAUX, O. M. La torre. Realidad, Buenos Aires, v.1, n.2, 214-228, 1947. [Consultado na edição fac-similar: Realidad. Prólogo de Luis García Montero. Sevilla: Renacimiento, 2007. 6v.]

A descoberta de Aub. Diário de Notícias. 1961. [Esses dados de referência constam no artigo recortado do jornal que se encontra junto à correspondência de Max Aub depositada no arquivo da Fundación Max Aub. F.A.A. C.49-131]

Ensaios reunidos. 1942-1978. De A cinza do purgatório até Lipros na mesa. Org., introd. e notas de Olavo Carvalho. Rio de Janeiro: Topbooks/ Univercidades, 1999.

Ensaios reunidos. 1946-1971. Org., introd. e notas de Olavo Carvalho. Rio de Janeiro: Topbooks/ Univercidades, 2005.

Historia da literatura ocidental. Ed. Joaquim Campelo Marques. São Paulo: Leya, 2011. v.1.

RESUMO - O trabalho apresenta o papel pioneiro de Otto Maria Carpeaux como mediador da literatura das "duas Espanhas" - a peninsular e a exilada - que se configuraram com a derrota do governo republicano na Guerra Civil Espanhola. Para tanto, desenvolve-se em dois movimentos rastreando alguns dos ensaios publicados por Carpeaux na imprensa e alguns dos vínculos que o próprio autor neles estabelece entre sua formação e seu interesse pela cultura espanhola. A articulação dos dois movimentos permite tra- 
çar o perfil desse humanista, bem como o da prática do pensamento comparatista que vertebra sua produção crítica, sempre orientada pela ética, por agudo critério estético e pela busca de compreensão do mundo em que viveu.

PALAVRAS-CHAVE: Otto Maria Carpeaux, Literatura comparada, Literatura das “duas Espanhas" no Brasil.

ABSTRACT - The following work presents the pioneering role of Otto Maria Carpeaux as a mediator of the literature of the "two Spains" - the peninsular and the exiled - shaped after the Republican government was defeated at the Spanish Civil War. To this end, it develops in two movements: it traces back some of the essays published by Carpeaux in the press and some of the links the author himself establishes between his education and his interest in the Spanish culture. The dialogue between these two movements allows us to delineate this humanist's profile, as well as that of the comparative thought that structures his critical production, always guided by ethics, by acute aesthetic criteria and by the search to understand the world in which he lived.

KEYWORDS: Otto Maria Carpeaux, Compared literature, The literature of "two Spains" in Brazil.

Valeria De Marco é professora de Literatura Espanhola na Faculdade de Filosofia, Letras e Ciências Humanas da Universidade de São Paulo. Sua publicação mais recente vinculada ao tema deste trabalho é: AUB, M. Campo francés. Edición, introducción y notas de Valeria De Marco. Madrid: Segorbe, Castalia: Fundación Max Aub, 2008. @ - valmarco@usp.br

Recebido em 18.1.2013 e aceito em 31.1.2013. 